\title{
Confidence in the
}

\section{Judicial System and}

Court Experience:

\section{Evidence from Brazil}

\author{
JoElson Oliveira SAMPaio \\ Rodrigo de LoSSO dA Silveira BuENo \\ LUCIANA Gross CunHA
}

WORKING PAPER SERIES № 2014-11 
DEPARTMENT OF ECONOMICS, FEA-USP

WORKING PAPER № 2014-11

\title{
Confidence in the Judicial System and Court Experience: Evidence from Brazil
}

\author{
Joelson Oliveira Sampaio (joelsonssp@gmail.com) \\ Rodrigo de Losso da Silveira Bueno (delosso@fipe.org.br) \\ Luciana Gross Cunha (luciana.cunha@fgv.br)
}

\begin{abstract}
:
Although there is a literature that relates the determinants of confidence in the judicial system and utilization of the judiciary, there is a gap on the causal relationship between these two variables. The purpose of this paper is to examine the causal relationship between confidence in the judicial system and utilization of the judiciary in Brazil. To address this issue, we construct measures of the extent to which the main newspapers report government corruption in their front page during the period 20102013 distributed by the states: Minas Gerais, Pernambuco, Rio Grande do Sul, Rio de Janeiro, São Paulo and Distrito Federal. By examining how confidence in the judicial system affects the utilization of the judiciary, we used instrumental variable approach: IV Probit. We used the news of corruption (front page coverage of corruption) as instrumental variable. Confidence in the judicial system is the variable instrumentalized. Our results are based on four surveys conducted along 2010, 2011, 2012 and 2013. We created the Brazilian Confidence in Justice Index (BCJI) as a validity argument for our confidence measure. Our results evidence that confidence in the judicial system has a positive impact on utilization of the judiciary. People who have higher levels of confidence in the judicial system have a greater propensity to seek the judiciary. We also found that there is a positive relationship between confidence in the judicial system and utilization of the judiciary for some demographic variables such as income, education, age and race.
\end{abstract}

Keywords: Confidence in Justice; Institutions; Judiciary.

JEL Codes: K11; K30; K40. 


\title{
Confidence in the Judicial System and Court Experience: Evidence from Brazil
}

\author{
Joelson Oliveira Sampaio* \\ Faculdade de Economia e Administração (FEA-USP) \\ Rodrigo De Losso da Silveira Bueno** \\ Faculdade de Economia e Administração (FEA-USP) \\ Luciana Gross Cunha *** \\ São Paulo Law School (DIREITO-FGV)
}

(Draft: July 2014)

\begin{abstract}
Although there is a literature that relates the determinants of confidence in the judicial system and utilization of the judiciary, there is a gap on the causal relationship between these two variables. The purpose of this paper is to examine the causal relationship between confidence in the judicial system and utilization of the judiciary in Brazil. To address this issue, we construct measures of the extent to which the main newspapers report government corruption in their front page during the period 2010-2013 distributed by the states: Minas Gerais, Pernambuco, Rio Grande do Sul, Rio de Janeiro, São Paulo and Distrito Federal. By examining how confidence in the judicial system affects the utilization of the judiciary, we used instrumental variable approach: IV Probit. We used the news of corruption (front page coverage of corruption) as instrumental variable. Confidence in the judicial system is the variable instrumentalized. Our results are based on four surveys conducted along 2010, 2011, 2012 and 2013. We created the Brazilian Confidence in Justice Index (BCJI) as a validity argument for our confidence measure. Our results evidence that confidence in the judicial system has a positive impact on utilization of the judiciary. People who have higher levels of confidence in the judicial system have a greater propensity to seek the judiciary. We also found that there is a positive relationship between confidence in the judicial system and utilization of the judiciary for some demographic variables such as income, education, age and race.
\end{abstract}

Keywords: Confidence, Judicial System, Institutions, Judiciary

JEL classification: K11, K30, K40 


\section{1 - Introduction}

The well-functioning public institutions play an important role in economic development and public trust. A key variable in the effectiveness and legitimacy of public institutions is the confidence that they inspire among those whom they serve. However, in many nations, confidence in government, judicial system and other institutions has declined over time. People who have low levels of confidence in the judicial system, for example, may fail to seek justice to resort to other informal means to resolve their conflicts.

Several studies have analyzed the determinants of confidence in the judicial system. Lawrence (2001) shows that women have lower levels of confidence in the judicial system than men. Sherman (2002) shows that there are clear racial divisions of opinion about the criminal justice system's component institutions, though not about the system as a whole. He shows that whites have twice as much confidence in their local court systems than blacks. In measures of confidence in courts, race is again a factor that shows a big difference of opinion. Bennack (1999) found that people with higher incomes and more education reported greater confidence in most of the institutions examined. Jones, Weatherburn, and McFarlane (2008) found that confidence in the criminal justice system was generally found to be more prevalent among younger people, those who are better educated, and those on higher incomes. They also found that respondents who earned higher annual incomes were more confident that the justice system is effective in bringing people to justice, meeting the needs of victims, respecting the rights of the accused and treating the accused fairly.

There is also a literature that relates experience with the judicial system and levels of confidence in the judiciary. Benesh (2006) examines the potential effects of experience, perceptions of procedure, and institutions on confidence. She shows that a highly educated individual with experience as a juror and a strong understanding of the court system, who has a high level of baseline confidence in the institutions of government, and who lives in a state where judges are appointed and the crime rate is low will demonstrate the highest levels of confidence in state courts. On the other hand, a person without much formal education, who had been a defendant at least once in his or her life and does not consider him or herself to be informed about courts, who does not much trust the institutions of government and happens to live in a state with elected judges and a high crime rate will have the lowest levels. Benesh and Howell (2001) show that people who use the court assess that it does a good job. However, those who are not users claim it does a good job. The results found for the non-users can be related to more general factors of justice. Therefore, the concrete experience makes the reviews on the judiciary more outspoken.

Although there is a vast literature on confidence in the judicial system, there is a gap on the causal relationship between confidence in the judicial system and utilization of the judiciary. In this paper what we do differently from other papers is that we seek to identify the direction of causality between confidence 
in the judicial system and utilization of the judiciary. We used the Brazilian Confidence in Justice Index (BCJI) as a validity argument for our confidence measure. The BCJI is a measure of perception, which shows the opinion of the population about the confidence in the judicial system.

We address concerns about endogeneity in two ways. However, it remains strongly significant, supporting our claim of a plausibly causal effect running from confidence in the judicial system to utilization of the judiciary. To address this issue, we construct measures of the extent to which the main newspapers report government corruption in their front page during the period 2010-2013 distributed by the states: Minas Gerais, Pernambuco, Rio Grande do Sul, Rio de Janeiro, São Paulo and Distrito Federal. We used news of corruption because the media plays an important role in modern democracies, thus it provides a significant proportion of the information for citizens. By examining how confidence in the judicial system affects utilization of the judiciary, we use instrumental variable approach: IV Probit. We use the news of corruption (front page coverage of corruption) as instrumental variable. Confidence in the judicial system is the variable instrumentalized.

We used two measures of utilization of the judiciary: 1) we consider all the people who have had experience with the judiciary; 2) we consider only the cases in which people sought to justice by option. Analyze these two measures is important because in some cases people need to use the judiciary regardless of their level of confidence in the judicial system. We found that confidence in the judicial system has a positive impact on utilization of the judiciary. People who have higher levels of confidence in the judicial system present a greater propensity to seek the judiciary. We also found that there is a positive relationship between confidence in the judicial system and utilization of the judiciary for some demographic variables such as income, education, age and race. We also performed the same tests using the question of confidence in the judicial system instead the index of confidence in the judicial system (BCJI) that is calculated as the average from a set of nine questions covering the main aspects of confidence in the judicial system. Our results indicated again that confidence in the judicial system has a positive impact on utilization of the judiciary. One possible explanation for these results is that people can perceive the justice as a legitimate way to seek solution to their problems and would not hesitate to go to justice to solve their conflicts.

The paper proceeds as follows. Section 2 describes the data set and the methodology. Section 3 discusses the news of corruption and confidence in the judicial system. Section 4 discusses the results. Section 5 concludes the paper.

\section{2 - Methodology and Sample}

Our results are based on four surveys conducted along 2010, 2011, 2012 and 2013. These surveys were obtained through telephone contact during the period of forty-five months. The population of the survey is comprised of people distributed by states: Minas Gerais, Pernambuco, Rio Grande do Sul, Bahia, 
Rio de Janeiro, São Paulo and the Federal District, which combined represent approximately $60 \%$ of the population, according to the 2010 census conducted by the Brazilian Institute of Geography and Statistics (IBGE). The informant is an individual who represents the selected household, of any gender (male or female) and is 18 years old.

We use a method of proportional quota sampling, using the following quotas: gender, household income, education, age and economic status (economically active or not). The groups (strata) were proportionally distributed according to the 2010 Census and National Household Sample Survey 20091. Our sample consists of 4,685 respondents in 2010, 6,213 in 2011, and 6,049 in 2012. Table 1 provides an overview of the sample.

\section{Table 1. Sample Description}

The sample is distributed through 7 states, which together represent approximately $60 \%$ of the country's population, according to census data. The sample size was determined by the number of inhabitants in each state. The sampling frame was constructed to take the range of $95 \%$ and absolute sampling error of $2.5 \%$. Interviews were conducted via telephone.

\begin{tabular}{lccccc}
\hline \hline \multirow{2}{*}{ States } & \multirow{2}{*}{ Population } & \multicolumn{4}{c}{ Sample } \\
\cline { 3 - 6 } & 37.035 .456 & $\mathbf{2 0 1 0}$ & $\mathbf{2 0 1 1}$ & $\mathbf{2 0 1 2}$ & $\mathbf{2 0 1 3}$ \\
\hline São Paulo & 1691 & 2252 & 1614 & 1052 \\
Minas Gerais & 17.905 .134 & 810 & 1089 & 1164 & 898 \\
Rio de Janeiro & 14.392 .106 & 662 & 867 & 818 & 599 \\
Bahia & 13.085 .769 & 599 & 793 & 792 & 603 \\
Rio Grande do Sul & 10.187 .842 & 463 & 609 & 607 & 462 \\
Pernambuco & 7.929 .154 & 362 & 476 & 572 & 453 \\
Distrito Federal & 2.051 .146 & 95 & 127 & 482 & 458 \\
\hline Total & $\mathbf{1 0 2 . 5 8 6 . 6 0 6}$ & $\mathbf{4 6 8 2}$ & $\mathbf{6 2 1 3}$ & $\mathbf{6 0 4 9}$ & $\mathbf{4 5 2 5}$ \\
\hline \hline
\end{tabular}

The BCJI is calculated as the average from a set of nine questions covering the main aspects of confidence in justice. The respondent must issue his opinion on the justice regarding: confidence; speed in solving conflict; cost access; ease of access; political independence; honesty; ability to solve conflicts; panorama of the last 5 years and expectation for the next 5 years. Each question has the same weight within the index. The BCJI has a range between 0 and 10. For each question, we use the weighted average of responses. Thus, to compute weighted average of first question about confidence in justice we used four response categories that include: $1=$ Not at all confident, $2=$ Not very confident, $3=$ Fairly confident and 4 = very confident. Thus, to compute the BCJI, we sum all 9 questions, and then divide by 9 . Table 2 describes the BCJI and their components.

\footnotetext{
${ }^{1}$ The National Household Sample Survey - PNAD investigates every year and on a continuous basis, overall population characteristics, education, labor, income and housing, among others, for different periods of time according to the need of information about the country, as well as characteristics about migration, fertility, nuptiality, health, food security, and other topics.
} 
Table 2 describes the BCJI and their components.

The questions that form the questionnaire have four or five responses. Each question is identified by assigning an index $\mathrm{n}$ to its response, which also corresponds to a value assigned to that response. Thus, the first response, ie, the answer 0 , is assigned the value 0 . To the last response is assigned the value max, which can be 3 or 4 , depending on whether the question has four or five possible responses. Therefore $n=0,1,2,3$ or $n=0,1,2,3,4$. The answer's $n$ of question $\mathrm{q}$ is called nq. The value that is attributed to $\mathrm{nq}$ is $\mathrm{n}$, so the value $(\mathrm{nq})=\mathrm{n}$. For example, the response 0 (or first response) of the question $q=2$, ie, value $(02)=0$. Then, values are weighted according to the proportion of people who chose that response.

\begin{tabular}{llccccc}
\hline \hline & \multicolumn{5}{c}{ Weighted Average } \\
\cline { 3 - 6 } & \multicolumn{1}{c}{ BCJI } & $\mathbf{2 0 1 0}$ & $\mathbf{2 0 1 1}$ & $\mathbf{2 0 1 2}$ & $\mathbf{2 0 1 3}$ & Yll \\
\hline P1 & Confidence & 4.10 & 4.61 & 4.38 & 4.11 & 4.33 \\
P2 & Speed in solving conflicts & 1.99 & 1.99 & 1.91 & 1.87 & 1.94 \\
P3 & Costs access & 4.62 & 4.61 & 4.80 & 4.57 & 4.66 \\
P4 & Ease of access & 2.18 & 2.27 & 2.25 & 2.25 & 2.24 \\
P5 & Political independence & 3.40 & 3.55 & 3.65 & 3.40 & 3.51 \\
P6 & Honesty & 4.10 & 4.01 & 4.16 & 3.95 & 4.06 \\
P7 & Ability to solve conflicts & 4.22 & 4.43 & 4.46 & 4.18 & 4.34 \\
P8 & Panorama of the last 5 years & 5.91 & 5.86 & 5.85 & 5.58 & 5.81 \\
P9 & Expectation for the next 5 years & 7.22 & 7.52 & 7.30 & 7.27 & 7.26 \\
\hline \hline
\end{tabular}

Table 3 presents basic statistics of the BCJI for each year. Overall, the BCJI has not changed much between 2010 and 2013. Institutions change over time, but they are path-dependent because individuals learn, organizations develop, and ideologies form in the context of a particular set of formal and informal rules (North, 1990). North's view, institutional change is generally incremental rather than sudden, an accumulation of many small changes rather than occasional large changes. It is therefore natural that the index does not change in the short term. Although the BCJI has not changed, there are important differences between a pool of demographic and economic variables as race, income, age, gender, labor education, experience with the justice and knowledge on the judicial. 
Table 3. Descriptive statistics for BCJI

Descriptive statistics for BCJI in 2010, 2011, 2012 and 2013. The BCJI is calculated as the average from a set of nine questions covering the main aspects of confidence in justice: Confidence (P1); Speed in solving conflicts (P2); Cost access (P3); Ease of access (P4); Political independence (P5); Honesty (P6); Ability to solve conflicts (P7): Panorama of the last 5 years (P8) Expectation for the next 5 years (P9).

\begin{tabular}{|c|c|c|c|}
\hline Weighted Average & Std. Dev. & Min. & Max. \\
\hline \multicolumn{4}{|c|}{2010} \\
\hline 4.19 & 1.24 & 0.25 & 8.70 \\
\hline \multicolumn{4}{|c|}{2011} \\
\hline 4.29 & 1.31 & 0.25 & 9.07 \\
\hline \multicolumn{4}{|c|}{2012} \\
\hline 4.31 & 1.30 & 0.25 & 9.35 \\
\hline \multicolumn{4}{|c|}{2013} \\
\hline 4.13 & 1.32 & 0.25 & 9.07 \\
\hline \multicolumn{4}{|c|}{ All Years } \\
\hline 4.23 & 1.30 & 0.25 & 9.35 \\
\hline
\end{tabular}

\section{3 - News of Corruption as instrument for Confidence in the Judicial System}

There is a substantial literature that explores the relationship between the variation in perceptions of corruption and confidence in public institutions. Societies with more trust and less corruption have better governance, stronger economic growth, spend more on redistribution, and have greater respect for the law among the citizenry (Uslaner, 2004). People respect the law because they believe that the justice system is fair and that they have been treated fairly (Tyler, 1990). Pharr (2000) shows that low levels of confidence in the judicial system over time are caused by scandals relentlessly covered in the media. He shows that society has reacted to corruption by losing trust in public institutions. Stulhofer (2004) found that perceptions of corruption in Croatia have a negative correlation with generalized trust. Examples of corruption scandals involving public officials are stories that are shown daily in modern mass media (RoseAckerman, 1999). Seligson (2002) used survey data for four Latin American countries to test the effects of corruption experiences on perceptions of the legitimacy of the political system at the individual level. He shows that exposure to corruption erodes belief in the political system and reduces interpersonal trust. Clausen, Kraay and Nuiri (2011) show that individuals who experience corruption and who report that corruption is widespread also tend to have lower confidence in public institutions. They also show that this correlation is robust to the inclusion of a large intended to capture the respondent's tendency to complain or report more negatively on corruption and confidence than might otherwise set of variables to control for respondent-level characteristics, including a number of proxies be objectively warranted. Rothstein (2000) argues that people are not likely to lose faith in others just because they have venal politicians. However, when the legal system fails to punish transgressors, be they other citizens or political leaders, people will no longer feel quite so warm toward their fellow citizens. Lambsdorff (1999) argues that the key to less corruption and more trust is an effective system of property rights and the rule of law. If the law is enforced 
on fair grounds, then people will be more likely to obey the law and confidence in the judicial system will be higher. However, if people feel they are treated unfairly, so they rely less on justice and will be less likely to obey the laws. Hellman and Kaufmann (2004) show that firms who perceive a great deal of crony bias in policymaking have less confidence in the judicial system, are less likely to use courts, are more likely to pay bribes, and are more likely to cheat on their taxes.

Perhaps respondents' perceptions of the prevalence of confidence in the judicial system drive their propensity to use the judiciary, but just as plausibly the opposite could be true: individuals who lack propensity to use the judicial might, as a result, express low levels of confidence in the judicial system. We address concerns about endogeneity in two ways. However it remains strongly significant, supporting our claim of a plausibly causal effect running from confidence in the judicial system to propensity to use the judiciary. To address this issue, we construct measures of the extent to which the main newspapers report government corruption in their front page during the period 2010-2013 distributed by the states: Minas Gerais, Pernambuco, Rio Grande do Sul, Rio de Janeiro, São Paulo and Distrito Federal.

Figure 1 shows the front page of one day and illustrates how Front Pages was constructed. We used news of corruption because the media plays an important role in modern democracies, thus it provides a significant proportion of the information for citizens. By examining how confidence in the judicial system affects the utilization of the judiciary, we use instrumental variable approach: IV Probit. We use the news of corruption (front page coverage of corruption) as instrumental variable. Confidence in the judicial system (BCJI) is the variable instrumentalized. If the portion of BCJI that is due to the news of corruption predicts higher level of utilization of the judiciary, this cannot reflect signaling or endogeneity. We therefore use the news of corruption as an instrument for BCJI. Our exogeneity hypothesis is that news of corruption affects the utilization of the judiciary only through confidence in the judicial system (BCJI). Brehm and Rahn (1997) show that a respondent's general feelings toward government exert influence over social trust. Thus, we control for confidence in the national government. We also control for gender, race, income, education, age in years and its squared term, all of which have been shown to influence confidence in institutions (Brehm \& Rahn, 1997). Given that our data is clustered by states, any effect arising from statelevel clustering can be corrected by way of robust standard errors. 
Figure 1: Front Page O Globo 19th May, 2011. The construction of Front Pages involves adding for a particular newspaper and for a particular month the fraction of each front page in the month devoted to covering corruption scandals. Here, we considered Area (News) / (Total Area) as the contribution of May 19th to the measurement of Front Pages for O Globo in May 2011.

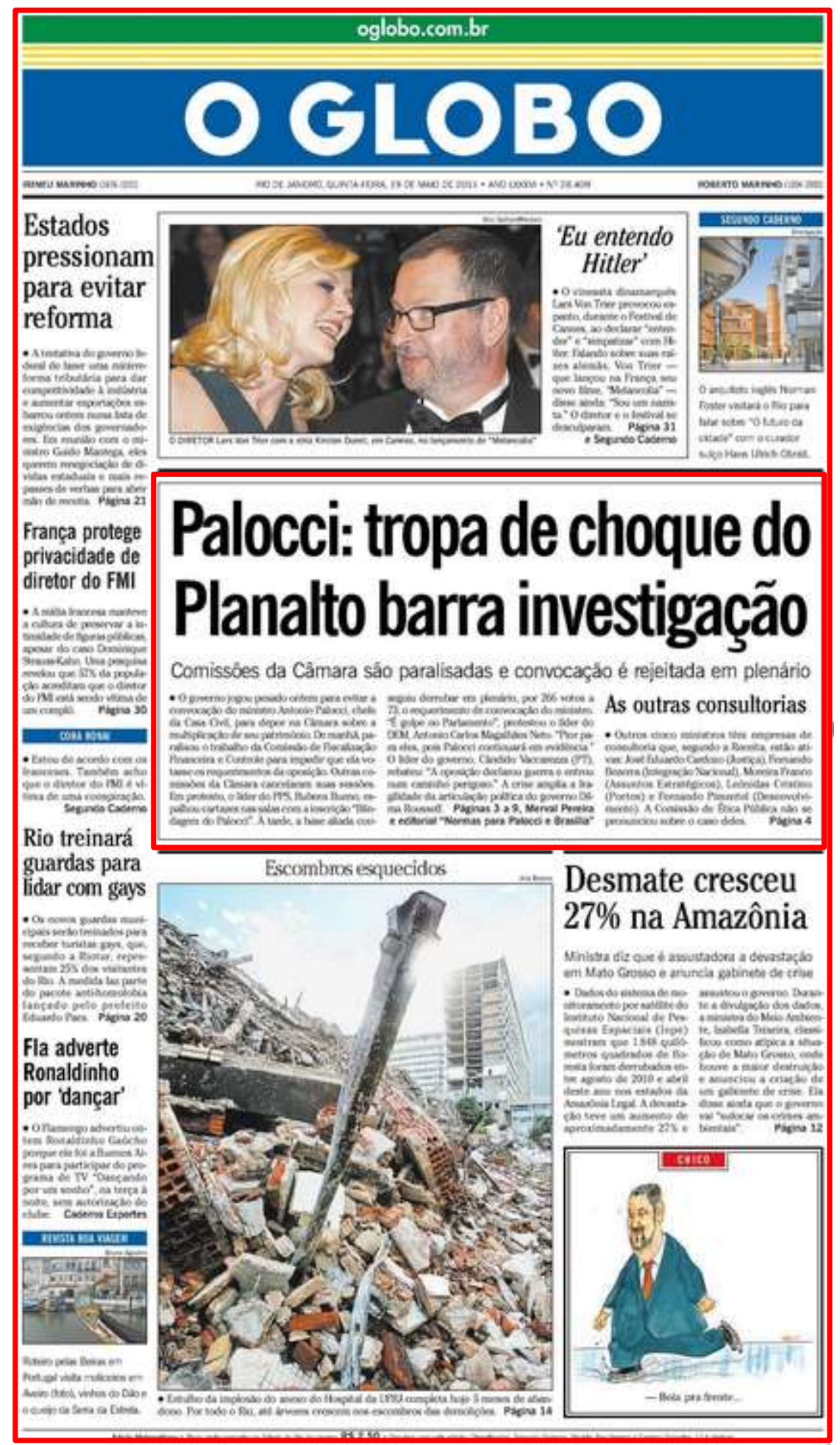

Determined to avoid, at any cost, the convening of the Minister Antonio Palocci (Casa Civil) to testify about increasing your personal wealth, the government worked hard yesterday. 
Figure 2 shows the evolution of "good" news of corruption overtime. We considered "good" news those related with arrest, condemnation or dismissal of corrupt people. The news are not stable overtime. There is difference between years and States. In some States, we could not to access old news of corruption. Thus, we have different periods in each State. Pernambuco, Rio Grande do Sul and Minas Gerais have low level of "news" of corruption. However, São Paulo, Rio de Janeiro and Distrito Federal have high level of news of corruption. The difference between these States may be related to the political influence that São Paulo, Rio de Janeiro and Distrito Federal have in Brazilian government.

In 2012, several newspaper covered the "mensalão" scandal that is a Portuguese neologism roughly meaning "big monthly stipend" was coined to describe clandestine payments made to congressional allies in return for support for its legislative agenda. The scandal broke in 2005 when the president of an allied party claimed in a newspaper interview that the Workers' Party (PT) was paying several congressmen $\$ 12,000$ a month. In the last quarter of 2012, the Supreme Court defined throughout the trial that sentenced 25 people in total; including politicians, businessmen and bankers who had ties to the corruption scandal that threatened to bring down Lula's government back in 2005. Because this, we can observe that the volume of news of corruption increased significantly in 2012 and 2013.

Figure 2. Evolution of "good" news of corruption distributed by the states: São Paulo, Rio de Janeiro, Pernambuco, Distrito Federal, Minas Gerais and Rio Grande do Sul. The graphs show the amount of "good" news of corruption in the period analyzed.
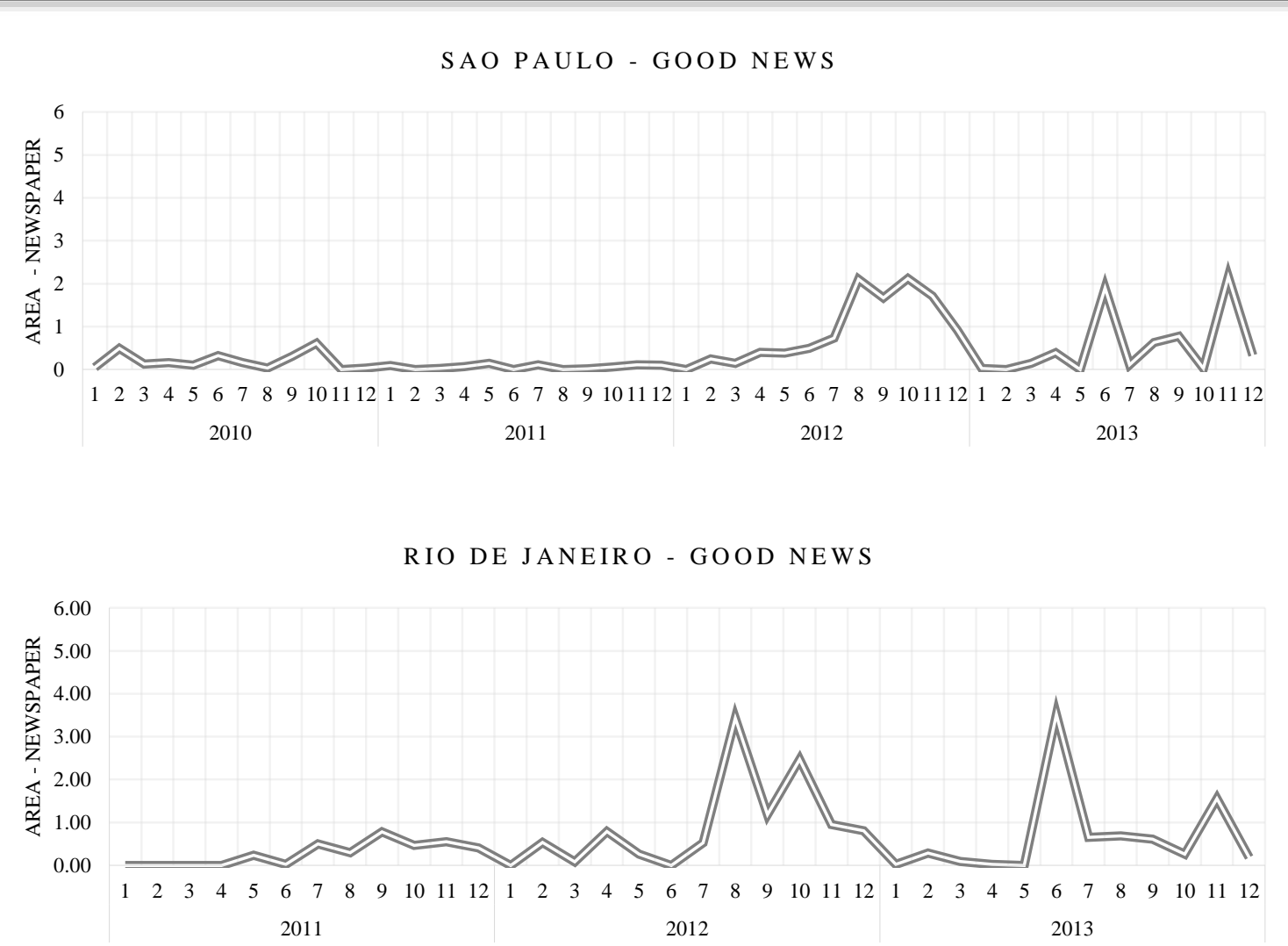
PERNAMBUCO - GOOD NEWS

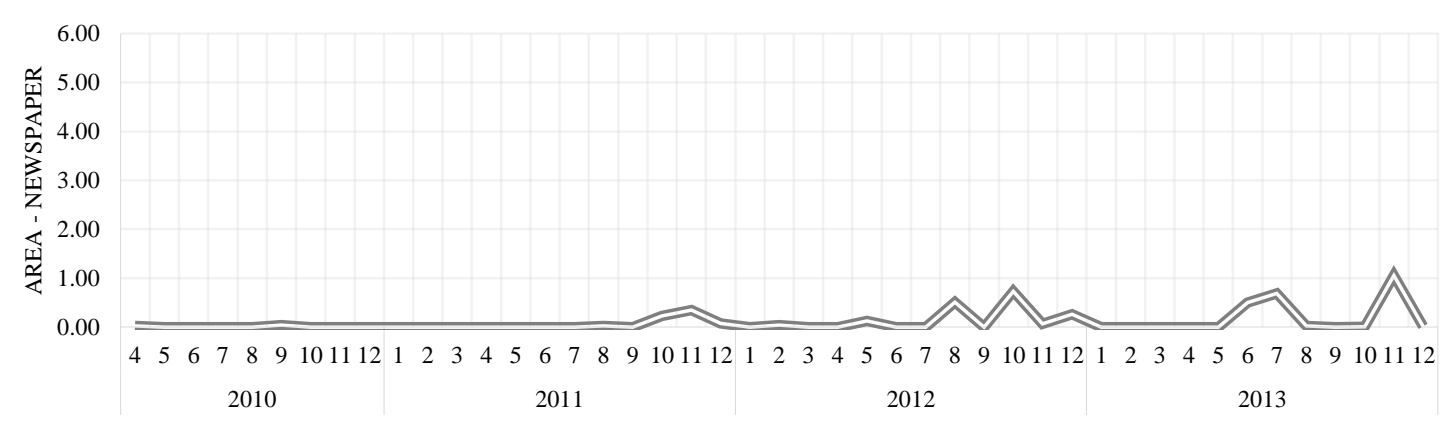

DISTRITO FEDERAL - GOOD NEWS
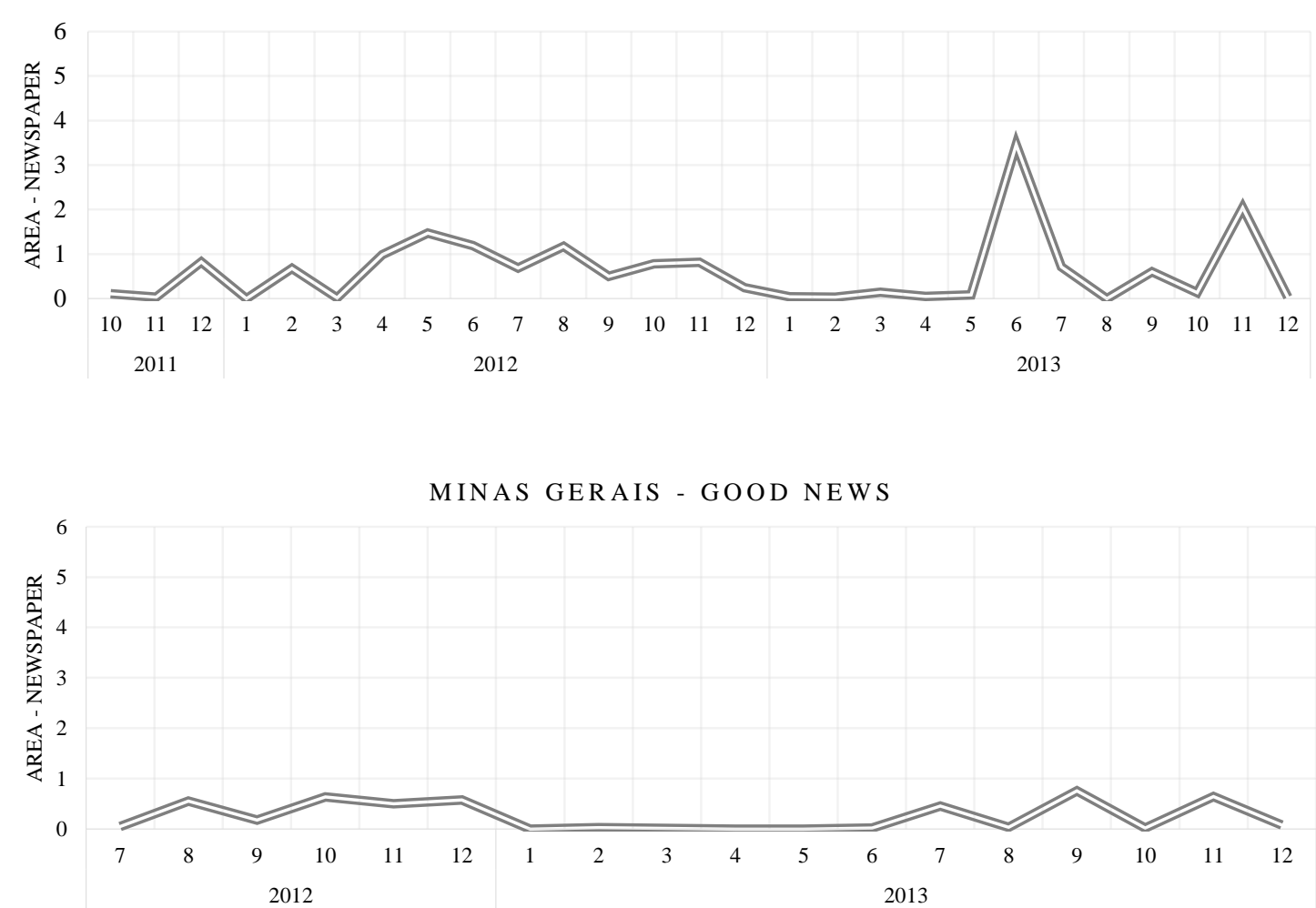

RIO GRANDE DO SUL - GOOD NEWS

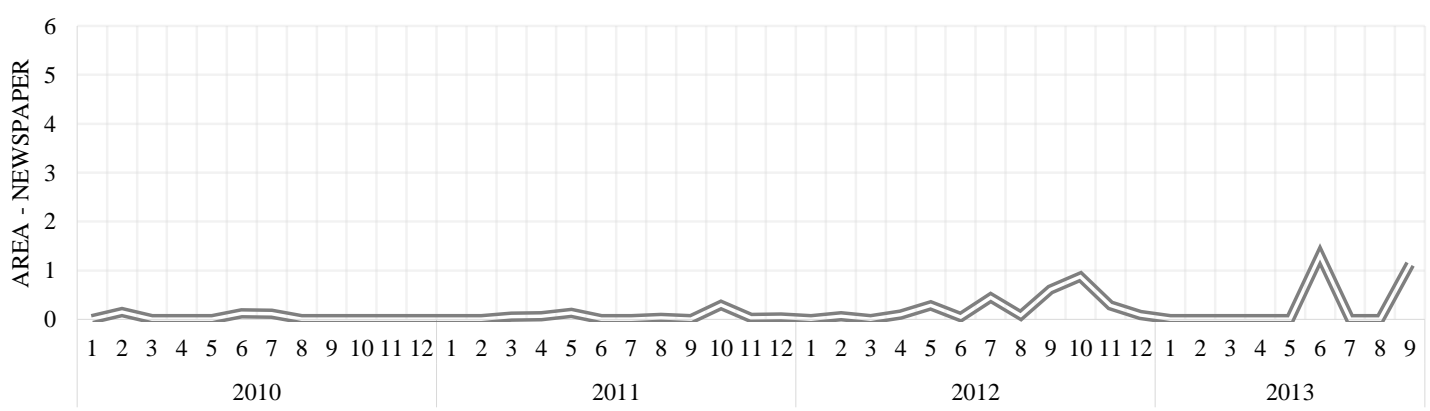


Figure 3 shows the evolution of "bad" news of corruption overtime. We considered "bad" news those related with impunity of corrupt people, corruption scandals and fraud. In general, most news of corruption are related to "bad" news that is a problem constant in the Brazilian political system, with many cases apparent at the federal, state, and municipal levels. Booth and Seligson (2009) shows that perceptions of corruption are strongly and negatively related to regime legitimacy. One way to measure this is through legitimacy of the motivations that lead citizens to trust or not in the judicial system. Thus, we expect that there is a negative impact of "bad" news of corruption on confidence in the judicial system.

Figure 3. Evolution of "bad" news of corruption distributed by the states: São Paulo, Rio de Janeiro, Pernambuco, Distrito Federal, Minas Gerais and Rio Grande do Sul. The graphs show the amount of "bad" news of corruption in the period analyzed.
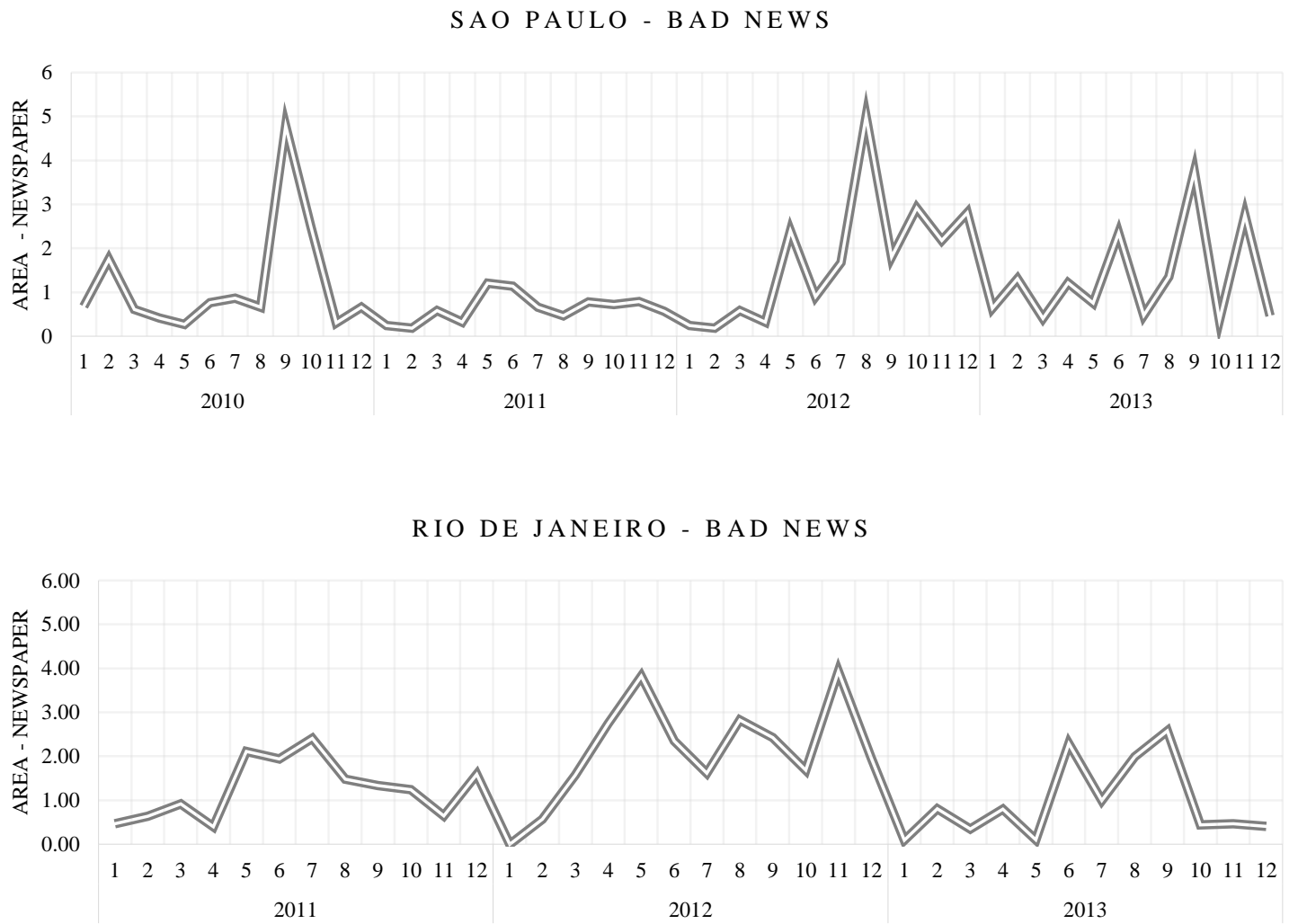

PERNAMBUCO - BAD NEWS

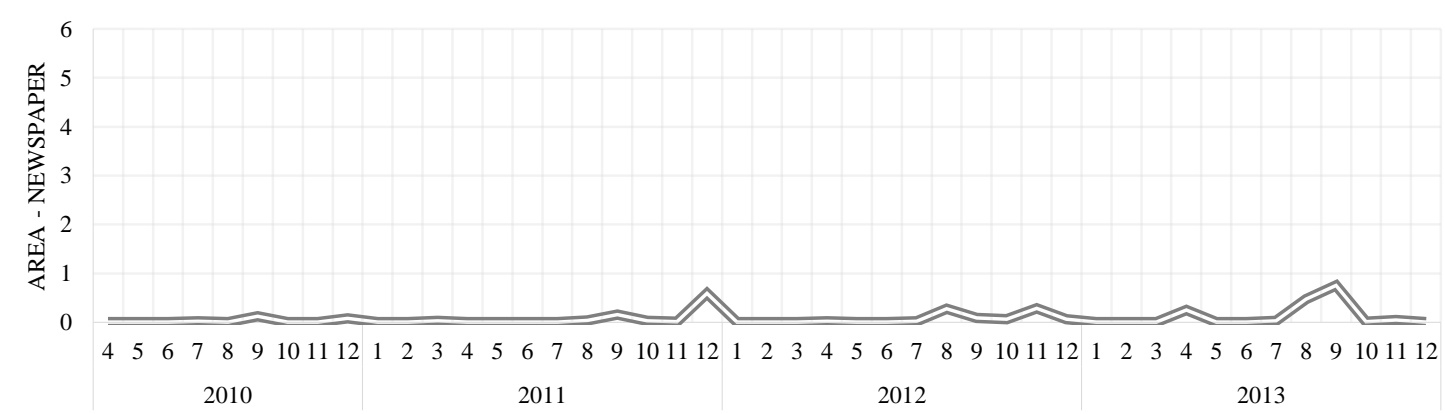


DISTRITO FEDERAL - BAD NEWS

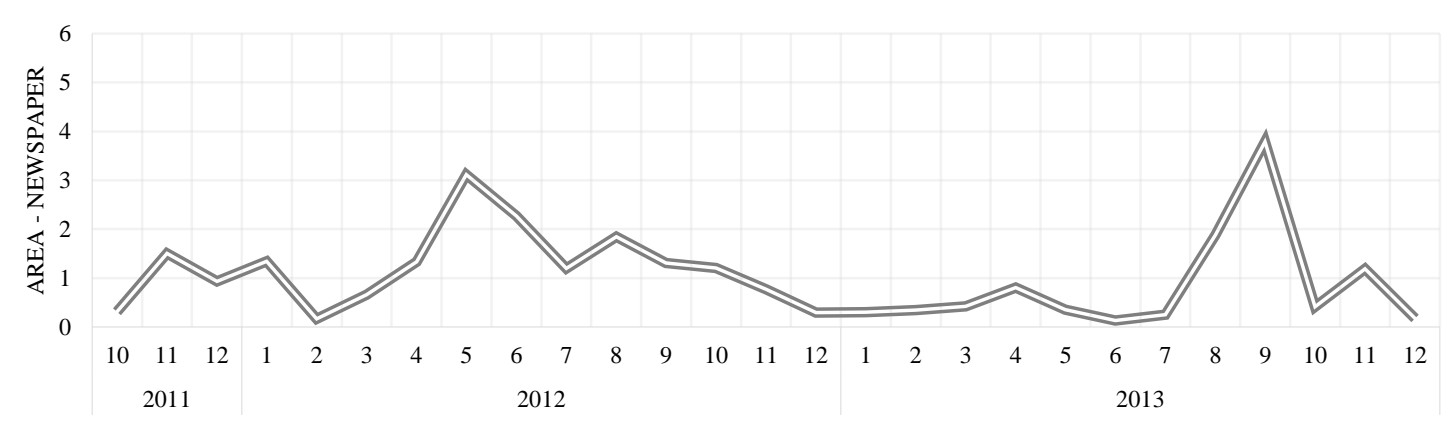

MINAS GERAIS - BAD NEWS

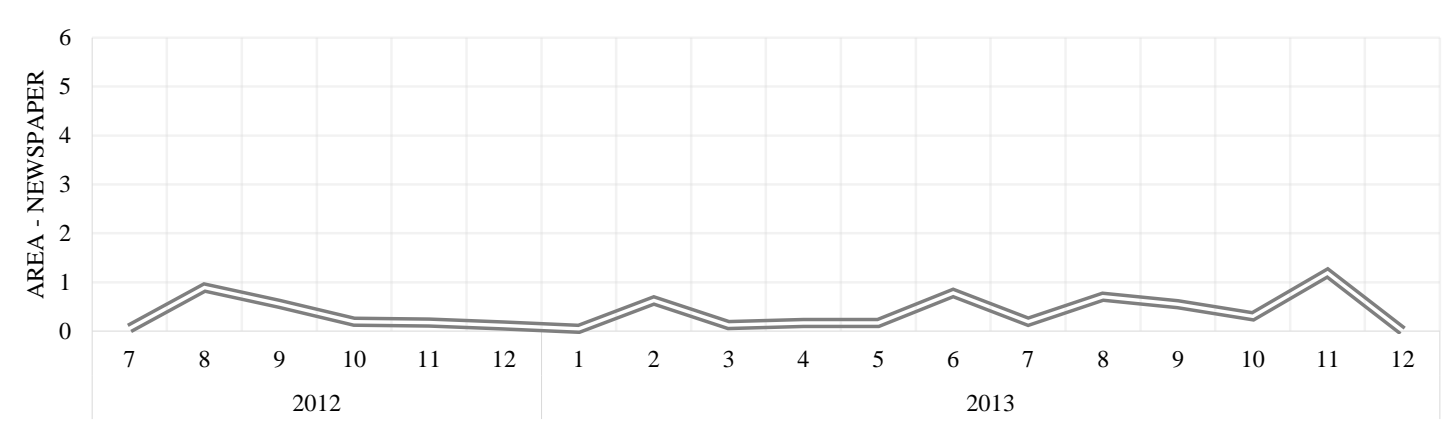

RIO GRANDE DO SUL - BAD NEWS

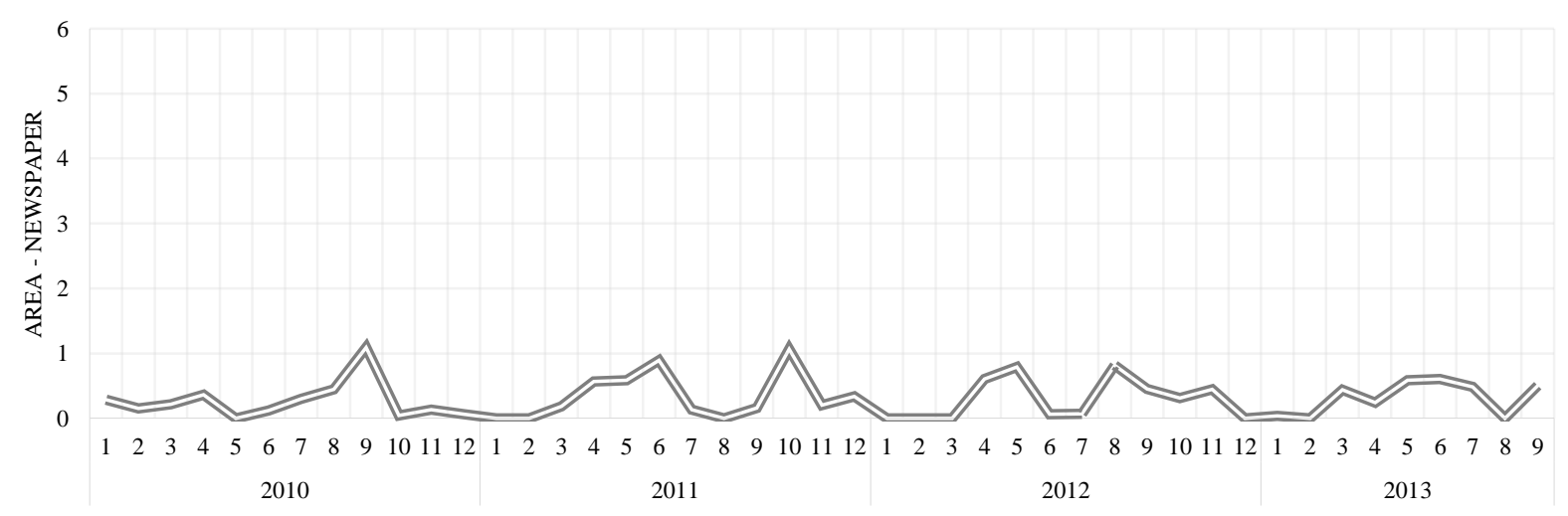

Table 4 shows that the mean for "bad" news of corruption is greater than "good" news of corruption. There are 2251 news in our data base that appear in front pages. There are 568 "good" news versus 1683 "bad" news. São Paulo has the highest number of corruption news. The biggest newspaper in Brazil is there. The number of "good" news in São Paulo is 214 versus 801 for "bad" news. However, some news are not local news but national news, for example, the scandal of corruption "Mensalão". São Paulo, Rio de Janeiro and Distrito Federal have many news of corruption. The means per month of "good" news are 0.43, 0.62 and 0.62 , respectively. The means per month of "bad" news are 1.22, 1.44 and 1.05, respectively. 
Sometimes, there is overlap between "good" and "bad" news of corruption. Thus, we develop three measures of the intensity of coverage of corruption scandals by newspapers. The variable of "bad" news was constructed to the total amount of front page space devoted to covering corruption cases in month $m$, in newspaper $n$. We performed the same calculation for the variable of "good" news. Due to the overlap, we created a new variable that is the difference between "bad" and "good" news.

Table 4. Descriptive statistics for Good and Bad News of Corruption

Descriptive statistics for good news of corruption to which the newspapers report government corruption in their front page during the period 2010-2013 distributed by the states: Minas Gerais, Pernambuco, Rio Grande do Sul, Rio de Janeiro, São Paulo and Distrito Federal.

\begin{tabular}{|c|c|c|c|c|c|c|}
\hline \multicolumn{7}{|c|}{ Panel A. "Good" News of Corruption } \\
\hline & Obs. (\#) & Mean & Median & Std. Dev. & Min. & Max. \\
\hline São Paulo & 214 & 0.43 & 0.14 & 0.63 & 0.00 & 2.17 \\
\hline Rio de Janeiro & 118 & 0.62 & 0.35 & 0.87 & 0.00 & 3.51 \\
\hline Pernambuco & 33 & 0.11 & 0.00 & 0.23 & 0.00 & 1.06 \\
\hline Distrito Federal & 113 & 0.62 & 0.50 & 0.78 & 0.00 & 3.45 \\
\hline Minas Gerais & 47 & 0.25 & 0.06 & 0.29 & 0.00 & 0.75 \\
\hline Rio Grande do Sul & 43 & 0.14 & 0.00 & 0.29 & 0.00 & 1.30 \\
\hline \multicolumn{7}{|c|}{ Panel B. "Bad" News of Corruption } \\
\hline São Paulo & 801 & 1.22 & 0.74 & 1.16 & 0.19 & 5.00 \\
\hline Rio de Janeiro & 359 & 1.44 & 1.41 & 1.03 & 0.00 & 3.93 \\
\hline Pernambuco & 41 & 0.08 & 0.00 & 0.16 & 0.00 & 0.76 \\
\hline Distrito Federal & 267 & 1.05 & 0.80 & 0.92 & 0.14 & 3.79 \\
\hline Minas Gerais & 86 & 0.38 & 0.19 & 0.34 & 0.01 & 1.19 \\
\hline Rio Grande do Sul & 129 & 0.31 & 0.22 & 0.30 & 0.00 & 1.09 \\
\hline
\end{tabular}

\section{4 - Results}

Table 5 shows the results related with confidence in the judicial system and utilization of the judiciary. In column (1) the dependent variable is the utilization of the judiciary. It is a binary variable that takes the value 1 if the respondent already had experience with the judicial system. In column (2) we used the same specification, but now the dependent variable considers only cases where people sought to court by option. Thus, the cases in which people had to seek to court by necessity were not considered, such as: contested divorce; addition formal sharing; interdiction special person; request retirement for reasons of health and disability, burglary, property embargoed; automobile accident with fatality; eviction; dissolution litigious society; precatory; contesting certificate and rectification name. In columns (1) and (2) we used "bad" news of corruption as instrumental variable. We used also the Brazilian Confidence in Justice Index (BCJI) as a validity argument for our confidence measure. The results shows that confidence in the judicial system has a positive impact on use of judiciary. Although in column (1) the result is not statistically significant, in column (2) where we used only the cases in which people sought to judicial system by option, 
the result is statistically significant at the $5 \%$ level. The advantage of column 2 is that the dependent variable is a cleaner measure of utilization of the judiciary.

In columns (3) and (4) we performed the same tests using "good" news of corruption as instrumental variable. In column (3) the result is statistically significant, but in column (4) it is not. Although the results of "good" news in the first stage may be strangers is important to note that "good" and "bad" news of corruption are sometimes simultaneous. That is, a newspaper may have "good" and "bad" news of corruption on the same day. The negative result of the variable "good" news of corruption may be related to the volume of "bad" news that appeared in the same period. The table 4 shows that the volume of "bad" news of corruption is greater than "good" news. The average for bad news is 0.75 versus 0.36 for "good" news. However, the column (3) shows that there is a positive relationship between confidence in the judicial system and utilization of the judiciary.

In columns (5) and (6) we used the balance of "bad" news minus "good" news of corruption as instrumental variable. In both (5) and (6) the results are not statistically significant. This result may be related to the overlap of "good" and "bad" news. Thus, by making the difference between bad and good news, the result can be greatly weakened. However, our results show that for "bad" news there is a positive impact of confidence in the judicial system on the utilization of the judiciary. This result contributes to the literature that explores the relationship between experience with the judicial system and confidence in public institutions. When the judiciary has the public trust, it has legitimacy and enables the consolidation of the rule of law (Levasseur, 2002). 
Table 5 - Determinants of the use of justice Index - IV PROBIT Regression

\begin{tabular}{|c|c|c|c|c|c|c|}
\hline & \multicolumn{6}{|c|}{ Utilization of the Judiciary } \\
\hline & Total & Optional & Total & Optional & Total & Optional \\
\hline & $(\mathbf{1})$ & (2) & (3) & (4) & (5) & (6) \\
\hline BCJI & $\begin{array}{l}-0.0244 \\
(-1.04)\end{array}$ & $\begin{array}{c}0.5350 * * \\
(2.22)\end{array}$ & $\begin{array}{c}0.4497 * \\
(1.90)\end{array}$ & $\begin{array}{l}-0.0059 \\
(-0.02)\end{array}$ & $\begin{array}{c}-0.0274 \\
(-1.17)\end{array}$ & $\begin{array}{l}-0.0237 \\
(-1.00)\end{array}$ \\
\hline $\begin{array}{c}\text { Confidence in the Federal } \\
\text { Government }\end{array}$ & $\begin{array}{c}-0.0561 * \\
(-1.84)\end{array}$ & $\begin{array}{c}-0.4845 * * * \\
(-2.78)\end{array}$ & $\begin{array}{c}-0.4228 * * \\
(-2.41)\end{array}$ & $\begin{array}{l}-0.0702 \\
(-0.23)\end{array}$ & $\begin{array}{c}-0.0537 * \\
(-1.76)\end{array}$ & $\begin{array}{c}-0.0560 * \\
(-1.82)\end{array}$ \\
\hline Female & $\begin{array}{c}-0.0536 * * \\
(-2.33)\end{array}$ & $\begin{array}{l}-0.0655 \\
(-1.07)\end{array}$ & $\begin{array}{l}-0.0090 \\
(-0.25)\end{array}$ & $\begin{array}{c}-0.1444 * * * \\
(-3.86)\end{array}$ & $\begin{array}{c}-0.0535 * * \\
(-2.33)\end{array}$ & $\begin{array}{c}-0.1457 * * * \\
(-6.32)\end{array}$ \\
\hline Black & $\begin{array}{c}0.0906 * * \\
(2.49)\end{array}$ & $\begin{array}{c}0.0699 * \\
(1.90)\end{array}$ & $\begin{array}{c}0.0855 * * \\
(2.33)\end{array}$ & $\begin{array}{c}0.0771 * * \\
(2.05)\end{array}$ & $\begin{array}{c}0.0906 * * \\
(2.49)\end{array}$ & $\begin{array}{c}0.0766 * * \\
(2.10)\end{array}$ \\
\hline Age & $\begin{array}{l}0.0453 * * * \\
(11.79)\end{array}$ & $\begin{array}{c}0.0383 * * * \\
(4.95)\end{array}$ & $\begin{array}{c}0.0451 * * * \\
(6.76)\end{array}$ & $\begin{array}{c}0.0396 * * * \\
(5.19)\end{array}$ & $\begin{array}{c}0.0453 * * * \\
(11.82)\end{array}$ & $\begin{array}{c}0.0393 * * * \\
(10.13)\end{array}$ \\
\hline Age squared & $\begin{array}{c}-0.0005 * * * \\
(-10.56)\end{array}$ & $\begin{array}{c}-0.0003 * * * \\
(-3.66)\end{array}$ & $\begin{array}{c}-0.0004 * * * \\
(-5.06)\end{array}$ & $\begin{array}{c}-0.0004 * * * \\
(-6.85)\end{array}$ & $\begin{array}{c}-0.0005 * * * \\
(-10.58)\end{array}$ & $\begin{array}{c}-0.0004 * * * \\
(-9.08)\end{array}$ \\
\hline $\begin{array}{c}\text { From } 2 \text { until } 4 \text { minimum } \\
\text { wages }\end{array}$ & $\begin{array}{c}0.0390 \\
(0.99)\end{array}$ & $\begin{array}{l}0.0300 \\
(0.65)\end{array}$ & $\begin{array}{l}0.0152 \\
(0.37)\end{array}$ & $\begin{array}{l}0.0681 \\
(1.61)\end{array}$ & $\begin{array}{l}0.0398 \\
(1.01)\end{array}$ & $\begin{array}{c}0.0688 * \\
(1.72)\end{array}$ \\
\hline $\begin{array}{l}\text { From } 4 \text { until } 12 \text { minimum } \\
\text { wages }\end{array}$ & $\begin{array}{l}0.1612 * * * \\
(3.81)\end{array}$ & $\begin{array}{c}0.1227 * \\
(1.76)\end{array}$ & $\begin{array}{c}0.1196 * * \\
(2.12)\end{array}$ & $\begin{array}{c}0.1870 * * * \\
(4.24)\end{array}$ & $\begin{array}{c}0.1619 * * * \\
(3.83)\end{array}$ & $\begin{array}{c}0.1875 * * * \\
(4.37)\end{array}$ \\
\hline $\begin{array}{c}\text { More than } 12 \text { minimum } \\
\text { wages }\end{array}$ & $\begin{array}{c}0.1986^{* * * *} \\
(4.16)\end{array}$ & $\begin{array}{c}0.1824 * \\
(1.83)\end{array}$ & $\begin{array}{c}0.1404 * * \\
(2.05)\end{array}$ & $\begin{array}{c}0.2841 * * * \\
(5.50)\end{array}$ & $\begin{array}{c}0.1993 * * * \\
(4.18)\end{array}$ & $\begin{array}{l}0.2850 * * * \\
(5.92)\end{array}$ \\
\hline Education & $\begin{array}{l}0.0271 * * * \\
(10.77)\end{array}$ & $\begin{array}{c}0.0162 \\
(1.59)\end{array}$ & $\begin{array}{c}0.0180 * * \\
(2.27)\end{array}$ & $\begin{array}{c}0.0285 * * * \\
(6.73)\end{array}$ & $\begin{array}{c}0.0271 * * * \\
(10.80)\end{array}$ & $\begin{array}{c}0.0286 * * * \\
(11.43)\end{array}$ \\
\hline Knowledge of justice & $\begin{array}{c}0.1366^{* * * *} \\
(4.43) \\
\end{array}$ & $\begin{array}{l}-0.0362 \\
(-0.41) \\
\end{array}$ & $\begin{array}{c}0.0079 \\
(0.09) \\
\end{array}$ & $\begin{array}{l}0.1129 \\
(1.26) \\
\end{array}$ & $\begin{array}{c}0.1376 * * * \\
(4.47) \\
\end{array}$ & $\begin{array}{c}0.1168 * * * \\
(3.74) \\
\end{array}$ \\
\hline Log pseudolikelihood & $-30951.1 * * *$ & $-30840.1 * * *$ & $-30948.6 * * *$ & $-30840.0 * * *$ & $-30953.2 * * *$ & $-30843.4 * * *$ \\
\hline Observations & 13,413 & 13,413 & 13,413 & 13,413 & 13,413 & 13,413 \\
\hline & & First Stage & V Results & & & \\
\hline Bad News & $\begin{array}{c}-0.0139 * * \\
(-2.06)\end{array}$ & $\begin{array}{c}-0.0138 * * \\
(-2.06)\end{array}$ & & & & \\
\hline Good News & & & $\begin{array}{c}-0.0202 * * * \\
(-2.76)\end{array}$ & $\begin{array}{c}-0.0202 * * * \\
(-2.76)\end{array}$ & & \\
\hline $\begin{array}{c}\text { Balance of Bad News } \\
\text { minus Good News }\end{array}$ & & & & & $\begin{array}{c}0.0014 \\
(0.22) \\
\end{array}$ & $\begin{array}{l}0.0014 \\
(0.22) \\
\end{array}$ \\
\hline Wald test of exogeneity:chi2 (1) & $4.83 * *$ & $4.96^{* *}$ & $2.75 *$ & 2.25 & 1.27 & 1.54 \\
\hline (p-value) & 0.023 & 0.021 & 0.085 & 0.112 & 0.136 & 0.123 \\
\hline
\end{tabular}

One problem in describing public trust in the judicial system is that it is multifaceted. According to Staats, Bowler and Hiskey (2005) judicial performance is a multidimensional concept. Therefore, we used two measures of confidence in the judicial system to give more robustness to our results. Table 6 shows also the results related with confidence in the judicial system and utilization of the judiciary. However, we use the question of confidence in the judicial system instead the index of confidence in the judicial system (BCJI). Table 6 reinforces our previous findings that confidence in the judicial system has a positive impact 
on utilization of the judiciary. In both columns (1) and (2) the results are statistically significant at the $1 \%$ and 5\% level, respectively. The results for the first stage are also statistically significant. We can observe that "bad" news of corruption have a negative relationship with confidence in the judicial system. In column (3) the result also is statistically significant, but in column (4) it is not. We have again a negative impact of variable "good" news of corruption on confidence in the judicial system. This result may be related to the volume of "bad" news of corruption that occurred in that period. Finally we examined the impact of confidence in the judicial system on utilization of the judiciary using the balance of "bad" news minus "good" news of corruption as instrumental variable. In both (5) and (6) the results are not statistically significant.

The results using news of corruption as instrumental variable can be explained due to two factors. The first is that the judicial system is one of the few alternatives that people have to resolve their conflicts. In this case, confidence in the judicial system would have a marginal effect on the utilization of the judiciary. The second is that news are information that people have about things that are not necessarily connected with them, for example, news of corruption. People have opinions on public services, despite not having experience with some of these services. This perception can be developed for the information transmitted by the media and by the knowledge that they have about that public service. 
Table 6 - Determinants of the use of justice Index - IV PROBIT Regression

\begin{tabular}{|c|c|c|c|c|c|c|}
\hline & \multicolumn{6}{|c|}{ Utilization of the Judiciary } \\
\hline & Total & Optional & Total & Option & Total & Optional \\
\hline BCJI & $\begin{array}{l}0.2479 * * * * \\
(3.24)\end{array}$ & $\begin{array}{l}0.1659 * * \\
(2.67)\end{array}$ & $\begin{array}{l}0.1810^{*} \\
(1.66)\end{array}$ & $\begin{array}{r}-0.0017 \\
(-0.01)\end{array}$ & $\begin{array}{l}-0.0061 \\
(-0.22)\end{array}$ & $\begin{array}{l}-0.0063 \\
(-0.23)\end{array}$ \\
\hline $\begin{array}{c}\text { Confidence in the Federal } \\
\text { Government }\end{array}$ & $\begin{array}{c}-0.3575 * * * \\
(-4.18)\end{array}$ & $\begin{array}{c}-0.2665^{* * *} \\
(-2.34)\end{array}$ & $\begin{array}{c}-0.2841 * * \\
(-2.29)\end{array}$ & $\begin{array}{l}-0.0727 \\
(-0.45)\end{array}$ & $\begin{array}{c}-0.0681 * \\
(-1.67)\end{array}$ & $\begin{array}{l}-0.0673 \\
(-1.63)\end{array}$ \\
\hline Female & $\begin{array}{l}-0.0329 \\
(-1.41)\end{array}$ & $\begin{array}{c}-0.1265 * * * \\
(-4.50)\end{array}$ & $\begin{array}{c}-0.0398 \\
(-1.63)\end{array}$ & $\begin{array}{c}-0.1441 * * * \\
(-6.01)\end{array}$ & $\begin{array}{c}-0.0519 * * \\
(-2.26)\end{array}$ & $\begin{array}{c}-0.1444 * * * \\
\quad(-6.25)\end{array}$ \\
\hline Black & $\begin{array}{c}0.1027 * * * \\
(3.01)\end{array}$ & $\begin{array}{c}0.0897 * * \\
(2.52)\end{array}$ & $\begin{array}{c}0.1030 * * * \\
(2.93)\end{array}$ & $\begin{array}{c}0.0770^{*} \\
(1.96)\end{array}$ & $\begin{array}{c}0.0906 * * \\
(2.49)\end{array}$ & $\begin{array}{c}0.0765 * * \\
(2.10)\end{array}$ \\
\hline Age & $\begin{array}{c}0.0415 * * * \\
(7.30)\end{array}$ & $\begin{array}{c}0.0391 * * * \\
(8.49)\end{array}$ & $\begin{array}{l}0.0443^{* * * *} \\
-8.39\end{array}$ & $\begin{array}{c}0.0397 * * * \\
(8.65)\end{array}$ & $\begin{array}{c}0.0457 * * * \\
(11.86)\end{array}$ & $\begin{array}{c}0.0396 * * * \\
(10.14)\end{array}$ \\
\hline Age squared & $\begin{array}{c}-0.0004 * * * \\
(-6.61)\end{array}$ & $\begin{array}{c}-0.0004 * * * \\
(-7.55)\end{array}$ & $\begin{array}{c}-0.0004 * * * \\
(-7.50)\end{array}$ & $\begin{array}{c}-0.0004 * * * \\
(-8.44)\end{array}$ & $\begin{array}{c}-0.0005 * * * \\
(-10.68)\end{array}$ & $\begin{array}{c}-0.0004 * * * \\
(-9.15)\end{array}$ \\
\hline $\begin{array}{c}\text { From } 2 \text { until } 4 \text { minimum } \\
\text { wages }\end{array}$ & $\begin{array}{c}0.0083 \\
(0.21)\end{array}$ & $\begin{array}{c}0.0468 \\
(1.11)\end{array}$ & $\begin{array}{c}0.0180 \\
(0.44)\end{array}$ & $\begin{array}{l}0.0681 \\
(1.62)\end{array}$ & $\begin{array}{c}0.0393 \\
(0.98)\end{array}$ & $\begin{array}{c}0.0683^{*} \\
(1.67)\end{array}$ \\
\hline $\begin{array}{c}\text { From } 4 \text { until } 12 \text { minimum } \\
\text { wages }\end{array}$ & $\begin{array}{l}0.1198 * * * \\
(2.61)\end{array}$ & $\begin{array}{c}0.1634 * * * \\
(3.45)\end{array}$ & $\begin{array}{c}0.1368 * * * \\
(2.88)\end{array}$ & $\begin{array}{c}0.1867 * * * \\
(4.29)\end{array}$ & $\begin{array}{c}0.1613 * * * \\
(3.79)\end{array}$ & $\begin{array}{c}0.1867 * * * \\
(4.32)\end{array}$ \\
\hline $\begin{array}{l}\text { More than } 12 \text { minimum } \\
\text { wages }\end{array}$ & $\begin{array}{c}0.1330 * * \\
(2.42)\end{array}$ & $\begin{array}{c}0.2414 * * * \\
(4.02)\end{array}$ & $\begin{array}{l}0.1576 * * * \\
(2.72)\end{array}$ & $\begin{array}{c}0.2837 * * * \\
(5.57)\end{array}$ & $\begin{array}{c}0.1985^{* * * *} \\
(4.11)\end{array}$ & $\begin{array}{l}0.2840 * * * \\
(5.82)\end{array}$ \\
\hline Education & $\begin{array}{r}0.0112 \\
(1.64)\end{array}$ & $\begin{array}{c}0.0189 * * \\
(2.56)\end{array}$ & $\begin{array}{c}0.0164 * * \\
(2.02)\end{array}$ & $\begin{array}{c}0.0285^{* * *} \\
(4.32)\end{array}$ & $\begin{array}{c}0.0271 * * * \\
(9.14)\end{array}$ & $\begin{array}{c}0.0287^{* * * *} \\
(9.65)\end{array}$ \\
\hline Knowledge of justice & $\begin{array}{c}0.0380 \\
(0.83)\end{array}$ & $\begin{array}{c}0.0557 \\
(1.16)\end{array}$ & $\begin{array}{c}0.0680 \\
(1.27)\end{array}$ & $\begin{array}{c}0.1120 * * \\
(2.27)\end{array}$ & $\begin{array}{c}0.1331 * * * \\
(4.18)\end{array}$ & $\begin{array}{c}0.1131 * * * \\
(3.50)\end{array}$ \\
\hline Log pseudolikelihood & $-38680.5^{* * * *}$ & $-38571.5^{* * *}$ & $-38685.7 * * *$ & $-38575.7 * * *$ & $-38694.7 * * *$ & $-38583.6 * * *$ \\
\hline servations & 13,414 & 13,414 & 13,414 & 13,414 & 13,414 & 13,414 \\
\hline & & First Sta & IV Results & & & \\
\hline Bad News & $\begin{array}{c}-0.0570 * * * \\
(-4.85)\end{array}$ & $\begin{array}{c}-0.0570 * * * \\
(-4.85)\end{array}$ & & & & \\
\hline Good News & & & $\begin{array}{c}-0.0567 * * * \\
(-4.12)\end{array}$ & $\begin{array}{c}-0.0567 * * * \\
(-4.12)\end{array}$ & & \\
\hline $\begin{array}{c}\text { Balance of Bad News minus } \\
\text { Good News }\end{array}$ & & & & & $\begin{array}{c}-0.0145 \\
(-1.19)\end{array}$ & $\begin{array}{c}-0.0145 \\
(-1.19)\end{array}$ \\
\hline Wald test of exogeneity: chi2 (1) & $6.72 * * *$ & $6.85 * * *$ & $3.95 * *$ & $5.68 * *$ & 1.35 & 1.45 \\
\hline (p-value) & 0.009 & 0.007 & 0.074 & 0.012 & 0.134 & 0.129 \\
\hline
\end{tabular}

\section{5 - Conclusion}

Although there is a vast literature that relates confidence in the judicial system and utilization of the judiciary, there is a gap on the causal relationship between these two variables. The purpose of this paper was to examine the causal relationship between confidence in the judicial system and utilization of the judiciary. To address this problem, we used the Brazilian Confidence in Justice Index (BCJI) as a validity argument for our confidence measure and news of corruption as instrumental variable. We seek to identify the direction of causality between confidence in the judicial system and utilization of the judiciary. 
We construct measures of the extent to which the main newspapers report government corruption in their front page during the period 2010-2013 distributed by the states: Minas Gerais, Pernambuco, Rio Grande do Sul, Rio de Janeiro, São Paulo and Distrito Federal.

We found that confidence in the judicial system has a positive impact on utilization of the judiciary. People who have higher levels of confidence in the judicial system have a greater propensity to use the judiciary. We also found that there is a positive relationship between confidence in the judicial system and utilization of the judiciary for some demographic variables such as income, education, age and race. We also performed the same tests using the question of confidence in the judicial system instead the index (BCJI). Our results were similar.

A possible explanation for these results may be due to judicial system to be one of the few alternatives that people have to resolve their conflicts. In this case, confidence in the judicial system would have a marginal effect on the propensity to use the judiciary. However, our results have important implications for confidence in the judicial system and utilization of the judiciary. Thus, it would be good if there were efforts to improve the determinants of confidence in the judicial system. In order to assess the influence of other aspects on the utilization of the judiciary, more precise estimates and measures of confidence institutional are needed.

\section{References}

Bennack, Frank A. 1999. How the Public Views the State Courts: A Report on the National Survey. Paper Presented at the National Conference on Public Trust and Confidence in justice System. Washington, DC. 14 May 1999.

Benesh, Sara C. 2006. Understanding Public Confidence in American Courts. Journal of Politics, 68: 697707.

Benesh, S. and S. Howell (2001). 'Confidence in the Courts: A Comparison of Users and Non-users.' Behavioural Sciences and the Law, 19: 199-214.

Clausen B. Kraay, A. and Nyiri, Z. 2011. Corruption and Confidence in Public Institutions : Evidence from a Global Survey. World Bank Economic Review, VOL. 25, NO. 2, pp. 212-249.

Cluzel, L., \& Sibony, A.-L. (2001). Qualité et évaluation de la justice: Colloque tenu a l'Ecole Nationale de la Magistrature - 21-22 mai 2001: Rapport de synthese. Mission de recherche Droit et Justice \& Ecole nationale de la magistrature.

Jones, C.; Weatherburn, D. and McFarlane, K.; New South Wales. Bureau of Crime Statistics and Research. Public Confidence in the New South Wales Criminal Justice System [online]. Sydney, N.S.W.: Bureau of Crime Statistics and Research New South Wales, 2008. Sydney, N.S.W.: Bureau of Crime Statistics and Research New South Wales, 2008. [20] p. Crime and justice bulletin: contemporary issues in crime and justice; ISSN: 1030-1046 ; no. 118. ISBN 9781921306273. Crime and justice bulletin: contemporary issues in crime and justice; ISSN: 1030-1046 ; no. 118. 
Availability:<http://search.informit.com.au/documentSummary;dn=664948566314414;res=IELHSS> ISBN: 9781921306273.

Hellman, Joel, and Daniel Kaufmann 2004. "The Inequality of Influence". Available at SSRN: http ://ssrn.com/abstract=386901 or doi:10.2139/ssrn.386901.

Lambsdorff, Johann. 1999. "Corruption in Empirical Research: A Review." Transparency International Working Paper.

Olson, S. M., \& Huth, D. A., (1998). Explaining Public Attitudes Toward Local Courts, Justice System Journal, 20, 41.

Pharr, S. J. 2000. Official's misconduct and public distrust: Japan and the trilateral democracies. In S. J. Pharr \& R. D. Putnam (Eds.), Disaffected democracies: What's troubling the trilateral countries (pp. 173-201). Princeton, NJ: Princeton University Press.

Rose-Ackerman, S. 1999. Corruption and government: Causes, consequences, and reform. New York: Cambridge University Press.

Roth, V. J., Bozinoff, L. \& MacIntosh, P. (1990). Public opinion and the measurement of consumer satisfaction with government services. Canadian Public Administration , 33, (4): 571-83.

Rothstein, B. 2000. Trust, social dilemmas and collective memories. Journal of Theoretical Politics, 12, 477-501.

Rottman, D.B., \& Tomkins, A. J. (1999). Public Trust and Confidence in the Courts: What Public Opinion Surveys Mean to Judges. Court Review, 36 (3), 24-31.

Salzman, R. and Ramsey, A. 2013. Judging the Judiciary: Understanding Public Confidence in Latin American Courts. Latin American Politics and Society, 55: 73-95.

Seligson, M. A. 2002. "he Impact of Corruption on Regime Legitimacy: A Comparative Study of Four Latin American Countries. Journal of Politics, I 408-433.

Sherman, L. 2002. "Trust and Confidence in Criminal Justice.” National Institute of Justice Journal. 248: $22-31$

Stulhofer, A. 2004. Perception of corruption and the erosion of social capital in Croatia 1995-2003. Politika Misao, XLI, 74-86.

Swindell, David and Janet Kelly. (2003). - The Case for the Inexperienced User: Rethinking Filter Questions in Citizen Satisfaction Surveys.ll American Review of Public Administration. 33(1): 91-108.

Tyler, Tom R. 1990. Why People Obey the Law, New Haven: Yale University Press.

Uslaner, E. M. 2002. The moral foundations of trust. Cambridge, UK: Cambridge University Press. 